\title{
How Islamic and Conventional Banks Use Discretionary Loan Loss Provision in Pakistan
}

\author{
Irsa Azam* \\ Department of Management Sciences, University of Gujrat, Punjab, Pakistan \\ Mamoona Majeed \\ Department of Commerce and Finance, Superior University, Lahore, Pakistan
}

\begin{abstract}
The purpose of this paper is to investigate the use of DLLP in the banking sector of Pakistan. First, the study identifies the factors affecting the use of DLLP in Islamic banks of Pakistan. Secondly, the study also tries to examine the difference between the use of discretion in Islamic and conventional banks. The study used secondary data collection method and applied regression technique for analysis. The study provide evidence that all the factors including CAR, bank size and profitability effect the use of DLLP in Islamic banks except LD and EBTP. The study also found that conventional banks are more involved in DLLP compared with Islamic banks. The reason may be that Islamic banks in Pakistan work under Sharia supervisory board and avoid the practices of earnings management. The sharia principled are based on fairness, justice, and equal chances of profit and loss. This study may be helpful for regulators who can make policies for financial statements to be more transparent. This study can also be useful for investors to get to know how much discretion banks has made on the main accounting item.
\end{abstract}

Keywords: Loan loss provision, Discretionary loan loss provision, Islamic banks, conventional banks, Earnings Management

DOI: $10.7176 / \mathrm{JPCR} / 49-03$

Publication date:June 30th 2020

\section{Introduction}

The internal and external stakeholders depend heavily on the reliability of annual reports of a business. The financial reports lead to the formation of crucial decision makings like capital raising and investment (Ghazali, Shafie \& Sanusi, 2015). These reports work just like a mirror to all stakeholders because they used it for checking the financial performance of a bank. Therefore, these reports must be reliable not only for stakeholders but also for the general public (Haat, Rahman \& Mahenthiran, 2008). (Mohammady, 2012) stated that the most important part of annual reports is income statement because the capital market relies on it. However, the transparency of financial reports depends mainly on management, auditors and directors. Their positive behavior would ultimately help in generating these reports valid (Haat et al. 2008).

Managers perform discretionary management of their earning either for the sake of their personal benefits or under the pressure of higher management. In these practices managers hide the true value of the business from investors (Alexander \& Hengky, 2017). (Healy and Wahlen, 1999) indicated that change in actual values of financial figures by managers to deceive a few partners is called earning management. As financial reports represent the financial health of a business so, the investors make major decisions based on them. If the reporting process involves the practices of earnings management, ultimately it will produce ambiguous financial statements. Which could affect the decision making process of investors negatively.

Different research studies found that banks are more involved in these practices. Banks managers are encouraged to make changes in financial statements and ambiguously show their profit. Loan loss provision(LLP) is the instrument that banks used for making changes in financial statements (Mohammady, 2012; Ghazali et al. 2015). Researchers identify that Islamic banks are the one which avoids being the part of (Earning Management) EM practices (Taktak et al., 2010a). While at the same time there are some studies providing evidence of Islamic banks using LLP to smooth their earnings (Hung \& Tran, 2018). Besides the evidence of different studies, the discretionary component of this variable in Pakistan is still missing.

Following (Othman \& Mersni, 2014) this study is using discretionary loan loss provision (DLLP) as a component to measure the practices of earning management. The purpose of this study is to identify the factors which effect the use of DLLP in Islamic banks of Pakistan. The second purpose is to examine the difference in the use of discretion between Islamic banks and conventional banks? In developing countries like Pakistan, banks considered to play a key role for the efficient distribution of resources. But, this favorable result could only be grasped if banks are associated with unfair activities. Earnings manipulation and centralization of powers are part of these activities. On the other hand, the responsibility of a bank should be the accurate disclosure of their assets, wealth and liabilities (Sheikh \& Quresshi, 2017).

Literature suggests that fair and accurate information on financial statements should be the responsibility of 
a bank (Mohammady, 2012). These financial reports are used for checking the financial performance of banks (Haat, Rahman \& Mahenthiran, 2008). Therefore, the quality of these reports must be reliable. However, as the financial reports are the sensitive document for determining the bank's most important component like profit. Managers have been recognized to utilize discretion usually allowed by the prevailing accounting standards (Ashfaq \& saeed, 2017). Available discretionary measures make the manipulation easy for managers. They used those measures for hiding the actual facts and yield the desired accounting numbers for stakeholders and investors (Kumari \& Pattanayak, 2017). If annual reports are the representation of the bank performance and managers still involve in making changes intentionally then it is clear that identification of main reasons behind such practices is still missing. Therefore, this study will examine the factors which effect the use of DLLP in Islamic banks of Pakistan. Moreover, the study will also examine the difference in the use of DLLP between Islamic banks and conventional banks.

The study will be useful for investors, regulators and auditors. This study gives awareness to regulators that which factors banks are using for DLLP and how can strong policies alleviate them. This study can also be useful for investors to get to know how much discretion banks has made on the main accounting item. Moreover, this study can also help auditors by giving information on which type of policies banks adopt for making these practices.

\subsection{Theoretical and Literature Review}

There is not a single definition of earnings management(EM) on which researchers could agree upon. So all type of activities which leads to changes in the accounting item of financial statements could be categorized as earning management except financial reporting fraud (Alexander \& Hengky, 2017). Any modification that firm makes in reporting the financial performance of a business to mislead its users is called EM (Schipper, 1989). The purpose includes misdirecting company stakeholders by doing manager's own judgment at the time of financial statements composition (Healy \& Wahlen, 1999). According to (Kumari \& Pattanayak, 2017) these practices of EM have put a question on the integrity of published accounting items. Research shows that banks are also part of these practices.

Earning management can be of two types discretionary or real earning management. Many research studies provide evidence that companies and banks are involved in changing their earnings (Shen \& Chih, 2005; Wang, Chen, Lee \& Shyu, 2012). This issue is more sensitive in banks because of the importance of banks for economic development. Banks play a key role in the growth and stability of a country (Hamdi \& Zarai, 2012). A manipulation in one sector can ultimately disturb the whole economy similarly likely to the financial depression which also originated from banks. Accurate and detailed information is missing between investors and bank managers. As the bank shows the wrong information to the shareholders. The investor makes future perdition about bank performance based on inaccurate data which can affect the stability of a bank (Palia and Porter, 2007).

The study relates to agency theory where bank managers do not care about investors. They always try to put their personal benefits first and then think about someone else concern. Considering these points in mind they make those strategies and plans which will help them to gain a personal advantage. These agency problems could be solved if investors have the authority to monitor and control the manager's behavior. The identification of EM practices is easy in manufacturing firm but difficult in banks (Macey \& Hara, 2003).

A large body of research provides evidence for the presence of EM practices in banks and the factors which can affect the use of DLLP. After that, researchers try to find out the difference in the use of DLLP if the nature of the bank changed like public banks, private banks, conventional as well as Islamic banks. Islamic banks run under different structures and goals, they focus on the equal chance of profit as well as losses. The Islamic banks in Pakistan work under Sharia principles and avoid the practices of earnings management. The sharia principled are based on fairness, justice and the balance between the chances of profit and loss (Octavia \& Florentina, 2018).

Literature has many research studies on conventional banks but the studies on Islamic banks provide mixed results. Islamic banks have Shariah Supervisory Boards for monitoring the financial products according to the compliance of shariah principals. So these banks are less likely to involve in making ambiguous accounting decisions (Quttainah, 2011). On the other hand, many studies go against the arguments of Islamic principles and declared that both banks behave similarly. Islamic banks act in the same way as conventional banks do. Both banks involve in DLLP for producing favorable outcomes (Octavia \& Florentina, 2018; Zoubi \& Al-Khazali, 2007).

\subsection{Factors affecting the DLLP \\ 2.1.1 Earning Management}

The relationship between EM and DLLP is significantly positive. When accounting earnings are high enough, managers are more tend to recognize provision. The more earning variability a bank has, will increase the chances of a bank manager to involve in smoothing earning through LLP (Pinho and Martins, 2009, Othman, 2014). LLP helps managers to smooth their earnings instead of showing segregated part of their income over time. Literature identifies that the most useful method for the identification of EM practices is earning before tax and provision. This relationship is directly proportional to each other. If the ratio of EBTP is low, then the mangers use discretion to decrease the LLP. If the ratio of EBTP is high, then the manager uses discretion in increasing the LLP. Therefore, 
the relationship is positive between DLLP and EBTP.

\subsubsection{Capital Management}

Another most important factor is capital management which is known as Capital Adequacy Ratio (CAR). Empirical findings of previous studies show that the relationship is either positive and negative between DLLP and CAR. Some studies reveal that banks with low capital ratio try to use discretion to present low DLLP (Kim \& Kross, 1998). All those banks enrich with capital can get the relaxation on strict monitoring by regulatory agencies (Taktak et al., 2010b). So they can get the benefit of using discretion in making ambiguous earnings and capital. Which dictates that there is a negative relationship between DLLP and CAR in Islamic banks.

\subsubsection{Loan to Deposit Ratio}

Studies prove that there is a negative relationship between earnings management and LD ratio. This ratio has been used for external finance proxy (Zoubi \& Al-Khazali, 2007). If the LD ratio is high, it depicts that banks have more loans then deposit. Which ultimately enforce managers to attract more customer's deposit and banks reports low LD ratio. Therefore, the association between these variables is significantly negative.

\subsubsection{Bank Size}

From all the factors affecting DLLP, the bank size is considered as the most important one. This factor has a strong impact on the earnings management behavior of managers. Studies show that if the size of the bank is large, then there is a strong indication of high DLLP. So there is a positive relationship between bank size and DLLP (Taktak et al., 2010b; Quttainah, 2011).

\subsubsection{Profitability}

Since profitability is the most critical component of any bank so there in DLLP literature. (Gunawan et al., 2015) stated that profitability is used as a measure to check the ability of a bank in making profit. This direct relationship dictates that the more the profit of a bank the higher will be the LLP. Managers try to make discretionary changes in profitability for showing a good picture of their business (Alexander \& Hengky, 2017).

\subsection{Methdology}

Pakistan banks are used as population in this study. Banks have great importance and role in gowth and economic development of a country. The sample consists of 5 commercial banks and 5 Islamic banks of Pakistan. Data is collected from the annual reports of banks available on their official websites. The period of the study is from 2010 to 2019. The study employs the panel regression technique for the estimation of this model. Data is a balanced panel so a balanced panel data technique has been applied.

\subsubsection{Earning Management}

The main accrual of the banking sector is LLP. This substitute is further splited into two parts: Discretionary and non-discretionary accruals.

DLLP represents that part of LLP on which managers make manipulation. Whereas NDLLP consist of that part which is out of control of bank managers like bad debts, default risk etc (Beaver \& Engle 1996). So, the main model is given below:

LLP $=$ Non-discretionary LLP + Discretionary LLP

Since the NDLLP cannot be observed directly so the equation of LLP is estimated by following (Othman \& Mersni, 2014) approach.

$\mathrm{LLP}=\beta 0+\beta 1 \mathrm{NPL}+\beta 2 \Delta \mathrm{NPL}+\beta 3 \Delta \mathrm{TL}+\varepsilon$

Where: LLP is Loan loss provision, NPL equal to non-performing loan's opening balance, $\triangle N P L$ is the change in the value of non-performing loans and $\Delta \mathrm{TL}$ is computed by change in the value of total loan.

Table 1: Regression Results from Equation 1

\begin{tabular}{|l|c|c|c|}
\hline Variables & $\boldsymbol{\beta}$ & t-value & p-value \\
\hline C & 4.4501 & 0.4226 & $0.0000^{* * *}$ \\
\hline NPL & 0.8406 & 30.4541 & $0.0000^{* * *}$ \\
\hline $\boldsymbol{\Delta N P L}$ & 0.9355 & 7.0980 & $0.0000^{* * *}$ \\
\hline $\boldsymbol{\Delta}$ TL & 0.0376 & 2.0114 & $0.1017^{*}$ \\
\hline F-Statistics & 402.5223 & --- & $0.0000^{* * *}$ \\
\hline $\mathbf{R}^{\mathbf{2}}$ & \multicolumn{3}{|}{} \\
\hline
\end{tabular}

Note: $* * *, * *$ and $*$ indicate level of significant at $1 \%, 5 \%$ and $10 \%$, respectively.

First of all, we estimate equation one and the results are presented in table 1. The Hausman specification test has been employed to select between fixed or random effect model. Hausman test show siginificant statistics, so we move towards fixed effect model. The value of R2 is 0.9335 which shows highest explanatory power. Now, we will estimate the NDLLP using the estimated $\hat{\beta}, \hat{\beta}, \hat{\beta}$ and $\hat{\beta}$ from equation 1 .

$$
\mathrm{NDLLP}=\hat{\beta}_{0}+\hat{\beta}_{1} \mathrm{NPL}+\hat{\beta}_{2} \Delta \mathrm{NPL}+\hat{\beta}_{3} \Delta \mathrm{TL} .
$$

Finally, the DLLP is calculated by taking the difference between total LLP and estimated NDLLP. 
3.1.2 Regression Model

$$
\operatorname{DLLP}=\operatorname{LLP}-\left[\hat{\beta}_{0}+\hat{\beta}_{1} \mathrm{NPL}+\hat{\beta}_{2} \Delta \mathrm{NPL}+\hat{\beta}_{3} \Delta \mathrm{TL}\right] \ldots \ldots \ldots
$$

In regression model we use LLP as dependent variable and find the relationship between all those factors which can effect DLLP.

$$
\mathrm{DLLP}=\beta 0+\beta 1 \mathrm{EBTP}+\beta 2 \mathrm{CAR}+\beta 3 \mathrm{LD}+\beta 4 \mathrm{SIZE}+\beta 5 \mathrm{ROA}+\mathrm{Type}+\varepsilon \ldots \ldots . .(4)
$$

Where DLLP is discretionary loan loss provision, EBTP is calculated by earnings before taxes and provisions deflated by total assets for bank $i$ at the year $t, C A R$ is equal to capital adequacy ratio for bank $i$ at the year $t$, measured by average total equity over average total assets, Size computed as bank size for bank $i$ at the year $t$, expressed as natural log of asset, ROA is Profit after tax/ Total assets, Type is a dummy variable.

\subsection{Results and Discussion}

Table 2 shows the descriptive statistics of the results. Panel A displays the descriptive statistics of conventional banks. The average value of $\triangle \mathrm{NPL}$ is 4.37 ranging from 0.00 to 7.43 , which can deviate with slightly higher units 2.97. The average value of DLLP is 7.15 with maximum value of 8.017 and minimum 5.02, and the variation of mean is 0.83 units. The natural log of assets (size) state average value with 19.90 and its maximum value is 21.71 and minimum value is 15.80 units.

Similarly, panel B states the descriptive statistics for Islamic banks. The variable LLP represents the average value 6.17 with standard deviation of 0.83 units. The average value of $\Delta T L$ of Islamic banks are 6.7 with plus minus 1.23 units of mean.

Table 2: Descriptive Statistics

\begin{tabular}{|l|c|c|c|c|c|c|c|c|c|c|c|}
\hline Particular & $\Delta$ NPL & $\Delta$ TL & CAR & DLLP & EBTP & LD & LLP & NPL & ROA & SIZE \\
\hline Panel A: Conventional Banks \\
\hline Mean & 4.3693 & 5.9754 & 0.0924 & 7.1525 & 0.0522 & 0.5761 & 7.1525 & 6.9714 & 0.0137 & 19.909 \\
\hline Median & 5.7479 & 7.1674 & 0.0854 & 7.2956 & 0.0498 & 0.5536 & 7.2956 & 7.3383 & 0.0156 & 20.539 \\
\hline Maximum & 7.4323 & 8.2112 & 0.1802 & 8.0713 & 0.0968 & 0.8264 & 8.0713 & 8.1081 & 0.0346 & 21.710 \\
\hline Minimum & 0.0000 & 0.0000 & 0.0543 & 5.0232 & 0.0063 & 0.3976 & 5.0233 & 4.7517 & -0.0266 & 15.803 \\
\hline Std. Dev. & 2.9758 & 2.7498 & 0.0273 & 0.8375 & 0.0149 & 0.1230 & 0.8375 & 1.0446 & 0.0113 & 1.7397 \\
\hline \multicolumn{8}{|c|}{ Panel B: Islamic Banks } \\
\hline Mean & 3.7145 & 6.7541 & 0.1248 & 6.1713 & 0.0092 & 0.5724 & 6.1713 & 6.2639 & 0.0065 & 18.240 \\
\hline Median & 5.3511 & 6.8587 & 0.0837 & 6.2879 & 0.0064 & 0.5397 & 6.2879 & 6.4061 & 0.0057 & 18.191 \\
\hline Maximum & 7.1649 & 8.0378 & 0.3252 & 7.0780 & 0.0531 & 0.8137 & 7.0780 & 7.1954 & 0.1199 & 20.482 \\
\hline Minimum & 0.0000 & 0.0000 & 0.0465 & 4.0484 & -0.0404 & 0.3780 & 4.0484 & 4.1315 & -0.0285 & 16.621 \\
\hline Std. Dev. & 2.8072 & 1.2330 & 0.0865 & 0.6260 & 0.0199 & 0.1281 & 0.6260 & 0.6761 & 0.0209 & 1.0087 \\
\hline
\end{tabular}

The table 3 contains the correlation metrix results, the correlation between independent variables. The first part shows the correlation of variables in conventional banks and second part states the relationship in islamic banks. The highest coefficient of correlation is 0.57 between EBTP and CAR, showing that multicollinearity does not affect the data. In the same vein the Islamic banks panel B is showing the highest coefficient of correlation between EBTP and ROA, ensuring that data is save from multicollinearity problem.

\begin{tabular}{|c|c|c|c|c|c|}
\hline \multicolumn{6}{|c|}{ Panel A: Conventional Banks } \\
\hline Variables & EBTP & CAR & LD & SIZE & ROA \\
\hline EBTP & 1.0000 & & & & \\
\hline CAR & 0.5728 & 1.0000 & & & \\
\hline LD & 0.1790 & 0.2560 & 1.0000 & & \\
\hline SIZE & -0.0589 & -0.5280 & -0.2089 & 1.0000 & \\
\hline ROA & 0.4578 & 0.0134 & -0.0128 & 0.5516 & 1.0000 \\
\hline \multicolumn{6}{|c|}{ Panel B: Islamic Banks } \\
\hline Variables & EBTP & CAR & LD & SIZE & ROA \\
\hline EBTP & 1.0000 & & & & \\
\hline CAR & 0.0393 & 1.0000 & & & \\
\hline LD & -0.0865 & 0.4448 & 1.0000 & & \\
\hline SIZE & 0.4739 & -0.5561 & -0.3180 & 1.0000 & \\
\hline ROA & 0.5278 & 0.3184 & 0.2095 & 0.1029 & 1.0000 \\
\hline
\end{tabular}

Table 3: Correlation Matrix

This table 4 explain the ANOVA results for comparing the variables of islamic and conventional. The conventional banks have 7.15 LLP and Islamic banks have 6.17, which is showing that islamic banks have low LLP ratio. The NPL are 6.97 and 6.26 for conventional as well as islamic banks. The results indicate that islamic banks have less NPL as compared to conventional banks. The ratio of EBTP and CAR are lower in islamic banks 
and higher in conventional banks. Moreover, the ratio of DLLP is high in case of conventional banks and low for islamic banks. We conclude on the results that islamic banks are less involved in DLLP and conventional banks are more intending to use this discretion.

Table 4: Analysis of ANOVA

\begin{tabular}{|c|c|c|c|c|c|}
\hline \multirow[t]{2}{*}{ Variables } & \multicolumn{2}{|c|}{ Mean } & \multirow{2}{*}{$\begin{array}{c}\text { Mean } \\
\text { Difference }\end{array}$} & \multirow[t]{2}{*}{ t-value } & \multirow[t]{2}{*}{ p-value } \\
\hline & Conventional & Islamic & & & \\
\hline LLP & 7.1526 & 6.1713 & 0.9812 & 6.1575 & $0.0000^{* * *}$ \\
\hline NPL & 6.9715 & 6.2640 & 0.7075 & 3.7051 & $0.0000^{* * *}$ \\
\hline$\Delta \mathbf{N P L}$ & 4.3694 & 3.7145 & 0.6548 & 1.0636 & 0.2903 \\
\hline$\Delta \mathrm{TL}$ & 5.9754 & 6.7542 & -0.7787 & -1.6611 & $0.1002^{*}$ \\
\hline EBTP & 0.0522 & 0.0092 & 0.0429 & 11.6941 & $0.0000^{* * *}$ \\
\hline CAR & 0.9242 & 0.1249 & -0.0324 & -2.5034 & $0.0141^{* * *}$ \\
\hline LD & 0.5761 & 0.5725 & 0.0265 & 0.1371 & 0.8921 \\
\hline SIZE & 19.9098 & 18.2407 & 1.6690 & 5.3834 & $0.0000^{* * *}$ \\
\hline ROA & 0.0137 & 0.0066 & 0.0071 & 2.0647 & $0.0418^{* *}$ \\
\hline DLLP & 7.1526 & 6.1713 & 0.9812 & 6.1584 & $0.0000^{* * *}$ \\
\hline
\end{tabular}

Note: $* * *, * *$ and $*$ indicate level of significant at $1 \%, 5 \%$ and $10 \%$, respectively.

The main results of our regression model are given in Table 5. The value of EBTP is -0.6 stating that an average one-unit increase in EBTP leads to -0.6 units decrease in the value of DLLP and statistically significant. The CAR beta is positive and significant and 1\% level of significance. However, the LD have negative relationship with DLLP at -0.01 , but insignificant showing that the loan to deposit ration have no impact on discretion used by managers. Similar results found in ROA which is also representing no impact on DLLP. As we can see in the results of ANOVA table there is clear difference between the use of DLLP by conventional and Islamic banks. Now in this table of regression the variable TYPE is just proving our hypothesis with $1 \%$ level of significance. The relationship between TYPE and DLLP is statistically significant means that if banks are conventional then they are more involved in making discretion compared with Islamic banks similarly likely (Quttainah, 2011). The explanatory power of independent variables is $63 \%$ which is quite strong.

Table 5: Regression Results from Equation 4

\begin{tabular}{|l|c|c|c|}
\hline Variables & $\boldsymbol{\beta}$ & t-value & p-value \\
\hline C & -0.6978 & -6.0418 & $0.0000^{* * *}$ \\
\hline EBTP & -0.2231 & -1.6372 & $0.1053^{*}$ \\
\hline CAR & 0.2512 & 2.7623 & $0.0070^{* * *}$ \\
\hline LD & -0.0139 & -0.1972 & 0.8441 \\
\hline SIZE & 0.0811 & 8.0234 & $0.0000^{* * *}$ \\
\hline ROA & -0.1443 & -1.4433 & 0.1526 \\
\hline TYPE & -0.4104 & -3.3067 & $0.0013^{* * *}$ \\
\hline F-Statistics & 24.4991 & --- & $0.0000^{* * *}$ \\
\hline R $^{2}$ & \multicolumn{3}{|l}{} \\
\hline
\end{tabular}

Note: $* * * * *$ and $*$ indicate level of significant at $1 \%, 5 \%$ and $10 \%$, respectively.

\subsection{Conclusion}

The purpose of the study is to carefully analyze all those factors which can affect the use of DLLP in Islamic banks. Those factors include EBTP, CAR, LD ratio, bank size and profitability. The results declare that these factors have a significant impact on DLLP except LD ratio and EBTP. Secondly we also try to examine the change in the use of DLLP in Islamic and conventional banks. Our study provides evidence that Islamic banks are reluctant in the use of discretion, compared with conventional banks. The results go similar with (Quttainah, 2011) who declared that religion have an impact on managers accounting decision making process.

Future researchers can take more samples and include investment banks and development banks in their samples. Further they can make comparisons between financial and non-financial institutions.

\section{References}

Alexander, N. (2017). Factors affecting earnings management in the Indonesian stock exchange. Journal of Finance and Banking Review, 2(2), 8-14.

Ashfaq, S., \& Saeed, M. A. (2017). Financial performance of banking industry of pakistan: The role of corporate governance index and earnings management practices.

Beaver, W. H., \& Engel, E. E. (1996). Discretionary behavior with respect to allowances for loan losses and the behavior of security prices. Journal of Accounting and Economics, 22(1-3), 177-206.

Ben Othman, H., \& Mersni, H. (2014). The use of discretionary loan loss provisions by Islamic banks and 
conventional banks in the Middle East region: A comparative study. Studies in Economics and Finance, 31(1), 106-128.

Degeorge, F., Patel, J., \& Zeckhauser, R. (1999). Earnings management to exceed thresholds. The Journal of Business, 72(1), 1-33.

Ghazali, A. W., Shafie, N. A., \& Sanusi, Z. M. (2015). Earnings Management: An Analysis of Opportunistic Behaviour, Monitoring Mechanism and Financial Distress. Procedia Economics and Finance, 28, 190-201.

Healy, P. M., \& Wahlen, J. M. (1999). A review of the earnings management literature and its implications for standard setting. Accounting horizons, 13(4), 365-383.

Hamdi, F. M., \& Zarai, M. A. (2012). Earnings management to avoid earnings decreases and losses: empirical evidence from Islamic banking industry. Research Journal of Finance and Accounting, 3(3), 88-107.

Hassan Che Haat, M., Abdul Rahman, R., \& Mahenthiran, S. (2008). Corporate governance, transparency and performance of Malaysian companies. Managerial Auditing Journal, 23(8), 744-778.

Kim, M. S., \& Kross, W. (1998). The impact of the 1989 change in bank capital standards on loan loss provisions and loan write-offs. Journal of Accounting and Economics, 25(1), 69-99.

Kumari, P., \& Pattanayak, J. K. (2017). Linking earnings management practices and corporate governance system with the firms' financial performance: A study of Indian commercial banks. Journal of Financial Crime, 24(2), 223-241.

Macey, J. R., \& O'hara, M. (2003). The corporate governance of banks. Economic policy review, 9(1).

Mohammady, A. (2012). Earnings Quality Constructs and Measures. School of Economics, Kingston University London.

Othman, H. B., \& Mersni, H. (2014). The use of discretionary loan loss provisions by Islamic banks and conventional banks in the Middle East region. Studies in Economics and Finance.

Hatane, S. E., Octavia, F., \& Florentina, J. (2019, January). The Comparison of Earnings Management Practices in Indonesia's Islamic Banks and Conventional Banks. In International Conference on Tourism, Economics, Accounting, Management, and Social Science (TEAMS 2018). Atlantis Press.

Palia, D., \& Porter, R. (2007). Agency theory in banking: an empirical analysis of moral hazard and the agency costs of equity. Banks \& bank systems, (2, Iss. 3), 142-156.

Pinho, P. S. D., \& Martins, N. C. (2009). Determinants of Portuguese bank's provisioning policies: discretionary behaviour of generic and specific allowances.

Quttainah, M. A., Song, L., \& Wu, Q. (2013). Do Islamic banks employ less earnings management?. Journal of International Financial Management \& Accounting, 24(3), 203-Sheikh, N. A., \& Qureshi, M. A. (2017). Determinants of capital structure of Islamic and conventional commercial banks. International Journal of Islamic and Middle Eastern Finance and Management.

Schipper, K. (1989). Earnings management. Accounting horizons, 3(4), 91.

Shen, C. H., \& Chih, H. L. (2005). Investor protection, prospect theory, and earnings management: An international comparison of the banking industry. Journal of Banking \& Finance, 29(10), 2675-2697.

Taktak, N. B., Zouari, S. B. S., \& Boudriga, A. (2010). Do Islamic banks use loan loss provisions to smooth their results?. Journal of Islamic Accounting and Business Research.

Wang, C. Y., Chen, M. C., Lee, C. C., \& Shyu, S. D. (2012). Income smoothing and earnings management in the banking industry: evidence in Asian countries. International Research Journal of Finance and Economics, (99), 37-52.

Zoubi, T. A., \& Al-Khazali, O. (2007). Empirical testing of the loss provisions of banks in the GCC region. Managerial Finance, 33(7), 500-511. 